\title{
Effects of Riparian and Wetland Restoration on an Avian Community in Southeast Arizona, USA
}

\author{
J.W. Malcom* and W.R. Radke
}

San Bernardino National Wildlife Refuge, P.O. Box 3509, Douglas, AZ 85608, USA

\begin{abstract}
We used a before-after-control-impact study across three years to assess the effects of active riparian restoration on bird densities and community composition. Birds density post-restoration on actively-restored plots averaged 25 birds $\mathrm{ha}^{-1}$ versus 15 birds $\mathrm{ha}^{-1}$ on controls. We conclude that active restoration should be pursued to benefit bird populations.
\end{abstract}

\section{INTRODUCTION}

Riparian and wetland habitats of the Western United States are exceptionally diverse because of their higher productivity and more complex vegetation relative to surrounding areas [1,2], but the destruction and modification of riparian and wetland habitats has resulted in population declines for numerous species [3]. The declining populations have triggered various reactions, including the expansion of legal protection, a focus on restoring degraded habitats, or creating new habitats where complete destruction has occurred. Although riparian avian species have been studied extensivelyespecially those species afforded legal protection, e.g., southwestern willow flycatcher, Empidonax trailli exemiuslittle published information exists as to the effects of active restoration on avian communities. Passive restoration efforts, such as the removal of livestock from riparian areas, have received greater attention than active restoration efforts [4]. A notable exception is the work of Rood et al. [5] along the Truckee River in Nevada, where active water management was used to restore a riparian forest.

Active restoration of riparian habitats can include a variety of actions, including the installation of erosion control rock-and-wire gabions, mechanical manipulation of stream channel morphology, and pole planting of native riparian tree species, or, as Rood et al. [6] demonstrate, water regime management, among other techniques. Active wetland restoration can range from efforts to reestablish a native plant or animal community [7] to the wholesale creation of wetlands where they formerly existed [8]. All of these active restoration measures have the potential to affect numerous taxa, from the vegetative structure of the systems [9], to the invertebrate communities [10], to higher trophic groups such as birds.

We studied avian community response to active riparian and wetland restoration efforts in the southeastern corner of Arizona using a Before-After-Control-Impact (BACI) study design [11]. The research addresses two questions: 1., How does active wetland and riparian restoration affect bird densi-

*Address correspondence to this author at the San Bernardino National Wildlife Refuge, P.O. Box 3509, Douglas, AZ 85608, USA; Tel: 1-520829-0181; E-mail: jacob.malcom@gmail.com ties relative to continuing passive restoration? 2., How does active wetland and riparian restoration affect bird community diversity relative to continuing passive restoration? We chose to monitor all bird species' response to active restoration efforts for two reasons: first, birds are a trust group of the U.S. Fish and Wildlife Service, and second, they are highly visible species that may be used in ecosystem assessment $[12,13]$. We compare changes in bird density, avian species richness, and community composition across three years (one pre-restoration and two post-restoration).

\section{METHODS}

\section{Study Area}

Hay Hollow Wash is located on the eastern half of San Bernardino National Wildlife Refuge, Cochise County, Arizona, at an elevation of $1,200 \mathrm{~m}$. The wash is an incised channel (average incision depth $3 \mathrm{~m}$ ) that was formerly a broad floodplain dominated by flood-adapted plants and a central palustrine wetland [14]. The area had been heavily grazed for over a century when it was purchased by The Nature Conservancy in 1980, and then the U.S. Fish and Wildlife Service, at which point passive restoration by livestock removal began. The only water available in Hay Hollow prior to wetland restoration consisted of a single $6 \mathrm{~m}$ diameter livestock water tank.

The vegetation within Hay Hollow wash today is a mix of two distinct vegetation types: the first is riparian forest dominated by Populus fremontii with a smaller number of Salix gooddingii; the second type is grass and shrub dominated with Sorghum halpense and Sporobolus giganteus the dominant grasses and scattered Prosopis glandulosa and Atriplex cansecens. The grasses and shrubs are important factors in bank stabilization, and are assisting in reestablishing channel sinuosity and slowing erosion. Uplands along the margin of Hay Hollow wash are a mix of two distinct vegetation groups [15], desertscrub and desert grassland. Desertscrub areas are dominated by P. glandulosa and Larrea tridentata, with interspersed $A$. cansescens and various cacti (e.g., Opuntia spp.), grasses (e.g., Bouteloua spp.), and forbs. Desert grassland areas are dominated by Sporobolus giganteus, Sporobolus wrightii, and interspersed P. glandulosa and A. canescens. 
In 2005 we established six 2.9-ha plots, with three located in areas to be restored (treatments) and three located in areas not directly impacted by the restoration (controls). The polygons were randomly shaped and drawn in XMap (DeLorme, Inc. Yarmouth, Maine) over geo-referenced infrared aerial imagery; this map was then taken into the field and the corners of each polygon were flagged to define the plots (Fig. 1). We counted the number of Populus fremontii in each plot in 2005 and 2007 (there was no apparent change in 2006), and estimated the cover of Prosopis glandulosa, Sporobolus giganteus, and Sorghum halpense from aerial imagery combined with ground-truthing.

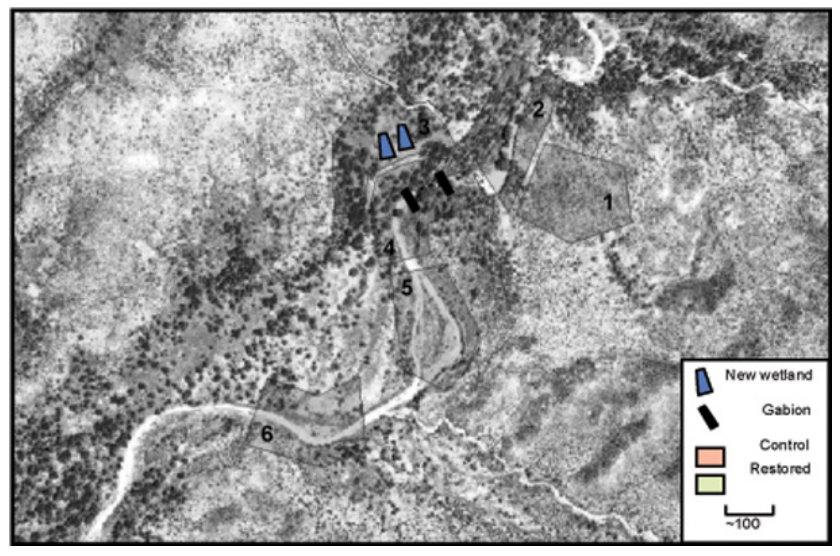

Fig. (1). Map of Hay Hollow Wash, San Bernardino National Wildlife Refuge, Arizona. Plot numbers on the map are referenced in text.

\section{Active Restoration}

Restoration efforts included the installation of two rockand-wire erosion control gabions in the restored riparian site in winter 2005 (Plot 4). Two wetlands were created in the restored desert grassland site in 2005-06 (Plot 3). Water from the wetlands was tailed into Hay Hollow Wash between the gabions, and flowed downstream into the desertscrub impact site (Plot 5). Plots 1 (desert grassland), 2 (riparian), and 6 (desertscrub) were not directly impacted by the restoration efforts: Plots 1 and 2 were upstream of the restoration sites, and Plot 6 was $\sim 300 \mathrm{~m}$ downstream, beyond the flow of tailed wetland waters.

\section{Bird Surveys}

Bird sampling was conducted approximately every 10d, for $30 \mathrm{~min}$ per plot, from April to August in 2005, 2006, and 2007, and followed a double independent observer methodology to account for different detection rates (see, e.g., [16]). Sampling started within $30 \mathrm{~min}$ of local sunrise, and all surveys were completed within $3.5 \mathrm{~h}$.

We used Chapman's [17] unbiased Lincoln-Peterson estimator,

$$
\hat{N}_{p}=\left[\frac{\left(n_{1 p}+1\right)\left(n_{2 p}+1\right)}{\left(m_{2 p}+1\right)}\right]-1,
$$

to estimate the total number of birds and species on each plot for each session, where $n_{l p}$ is the number of birds recorded by observer $1, n_{2 p}$ is the number of birds recorded by ob- server 2 , and $m_{2 p}$ is the number of birds seen in common. We relaxed the closure assumption of the method because all surveys were conducted during the breeding season, and based on our observations in the field, most individuals remain in relatively small areas throughout the morning. The Chapman estimator was also used to calculate the estimated species richness for each site. However, rather than using a count of the number of individuals per species, each species within a site was recorded as " 1 ".

Numerous species are seen on any given plot, and therefore the analysis must be species-contextual, that is, the simple difference in the number of birds observed cannot be used. For example, if observer 1 recorded three ash-throated flycatchers (Myiarchus cinerascens) and observer 2 recorded only one, then $n_{l p}=3, n_{2 p}=1$, and $m_{2 p}=1$. The values for a single plot on a single day are summed across species, then estimates are calculated. We used a two-way ANOVA with Tukey HSD contrasts to test for differences in bird density and species diversity between years and treatments. Density and diversity point estimates were used in independent analyses as the response variable. $\mathrm{R}$ [18] was used for analysis, with significance evaluated at the $95 \%$ confidence level.

Two sets of observers were hired during the course of the study, one pair in 2005 and 2006, the second pair in 2007; the authors either conducted or assisted with two surveys $(\sim 20 \%)$ each year permitting cross-validation. We used a two-way ANOVA (time-by-treatment) to assess densities for only the data in which JM and WR assisted in collection in comparison to the same analysis for the full dataset. To further test for observer, we compared the ratio of birds observed for Team 1 (WW and LW in Acknowledgements; years 2005 and 2006) to the ratio observed for Team 2 (RW and RR in Acknowledgements; year 2007) for a random subset of data that the two teams collected. The random data subset was chosen using a random numbers table. We used a one-way ANOVA with the ratio $n_{1}: n_{2}$ as the response and observers as the grouping variable.

In addition to bird density and species richness, we compared community similarity through time. We used Jaccard's index,

$$
J\left(x_{1}, x_{2}\right)=\frac{a}{a+b+c},
$$

where $a$ is the number of species in common between samples $\mathrm{x}_{1}$ and $\mathrm{x}_{2}, b$ is the number of species unique to sample $\mathrm{x}_{1}$, and $c$ is the number of species unique to sample $\mathrm{x}_{2}$, to compare communities. We made five contrasts between control and restored plot bird communities: control 2005 to restored 2005, control 2005 to control 2007, control 2005 to restored 2007, control 2007 to restored 2007, and restored 2005 to restored 2007. If restoration affects community composition, then we expect the initial communities (across treatments) and pre- and post-restoration control plot communities to be most similar, but we expect post-restoration control and restored plots to be least similar. If there is no effect, then we expect no pattern of similarity.

\section{RESULTS}

Passive restoration from 1980 through the present resulted in the establishment of an open riparian gallery that 
had not existed to any extent in nearly a century (Fig. 2a). Our active riparian restoration resulted in the deposition of nearly $1.5 \mathrm{~m}$ of relatively fine sediment in the wash bottom and increased water pooling in Plot 4 (Fig. 2b). Sediment deposition did not result in new tree establishment, but it recovered exposed roots of existing trees and permitted establishment of new annual vegetation. No new trees were established during the course of the study, but other wetland plants such as Cyperus sedges established within the wash. There was little direct impact to Plot 5 except that standing water or wetted substrates exist during the cooler months and may result in tree generation in the future. Active wetland restoration resulted in two new wetlands totaling $1525 \mathrm{~m}^{2}$ in Plot 3; the amount of available water increased approximately 50-fold (Fig. 3a), where previously there was a mix of Sporobolus giganteus and P. glandulosa (Fig. 3b). In addition to the available free water, wetland vegetation had begun to be established by the end of 2006, with a mix of the emergents Typha dominigensis and Scirpus americanus, and marginal Salix and Populus trees.

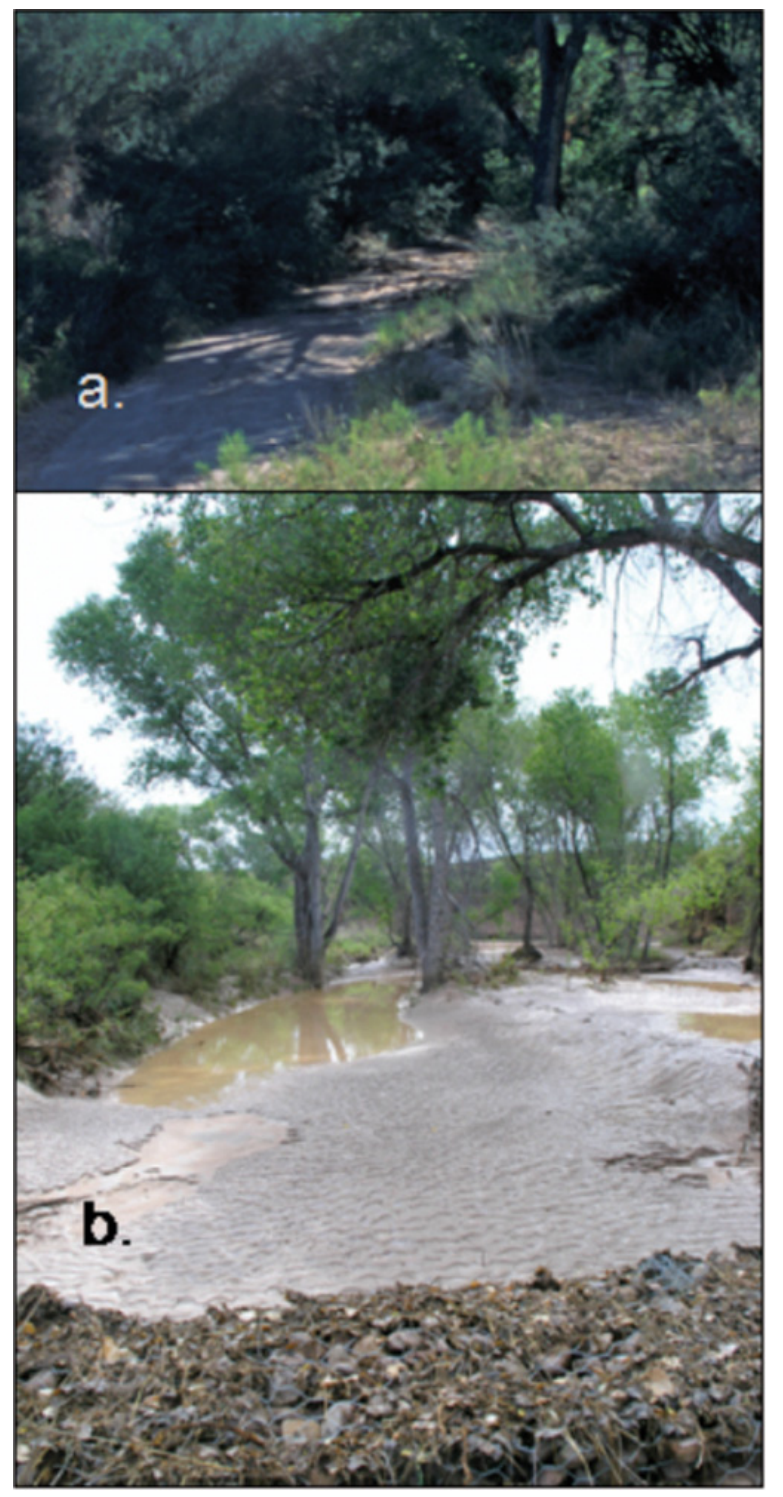

Fig. (2). The riparian corridor in Plot 4 before active restoration was undertaken (a), and afterwards (b). Exposed roots are visible in a., and the soil in b. represents approximately $45 \mathrm{~cm}$ new deposition.

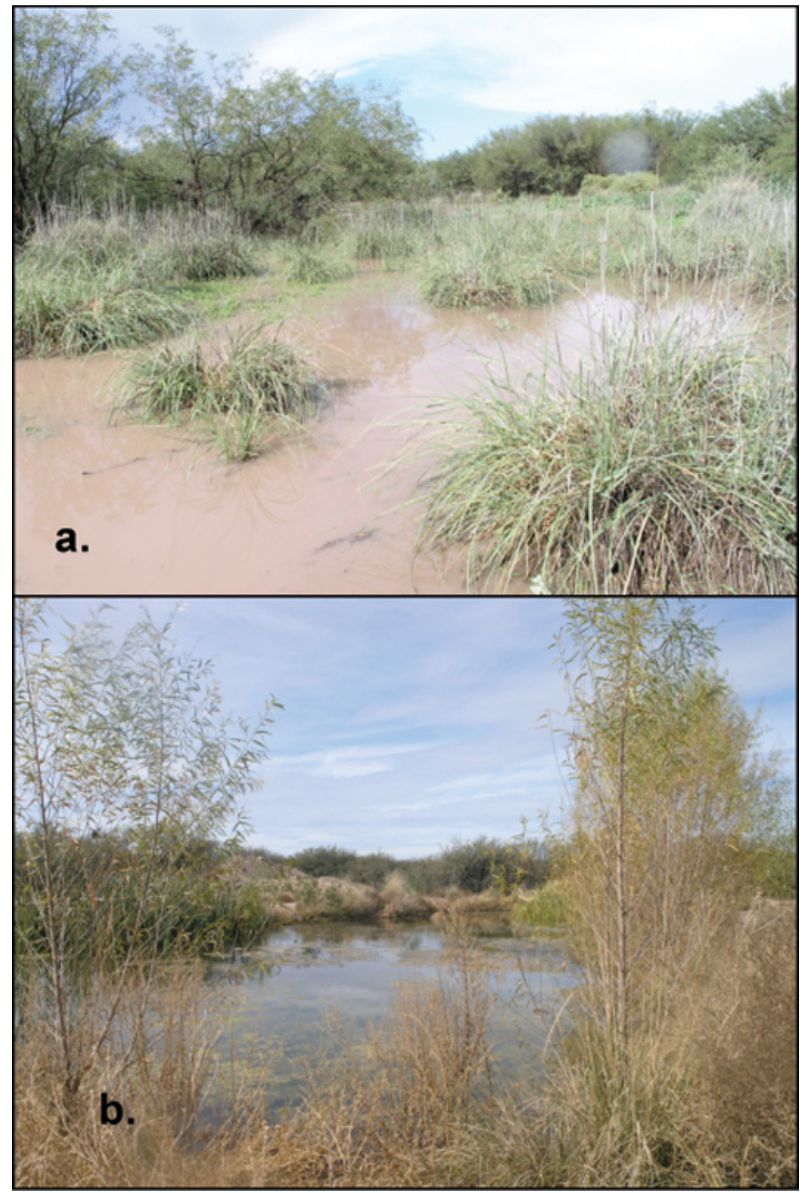

Fig. (3). The desert grassland of Plot 3 before two new wetlands were created (a), and afterwards (b). Fig. 3a. was taken immediately after a monsoon rain and exhibits sheet flooding.

We recorded 7545 bird sightings between 2005 and 2007 (2168 in 2005; 2541 in 2006; 2836 in 2007) of 112 species (Supplementary Materials Appendix 1). The active wetland and riparian restoration efforts had a positive effect on bird densities (Year-by-Treatment $F_{2,160}=4.90, P=0.008$ ), with an average of 2.3 additional birds per hectare in 2006 and an additional 8.4 birds per hectare in 2007 in restored versus control plots (Fig. 4a). Species richness was marginally higher with no difference in species richness in 2006, but six additional species were observed in 2007 on restored plots versus control plots (Year-by-Treatment $F_{2,160}=3.03, P=$ 0.051). Most of the difference between control and restored plots derived from a decline in species richness on control plots (Fig. 4b).

The density differences between control and restored plots were similar for both the reduced (JM and WRcollected data) and the full dataset. Significantly higher bird densities were observed on treatment plots after intervention for the reduced dataset (i.e., the author's observations only and the full dataset $\left.\left(F_{1,32}=10.81, P=0.002\right)\right)$. There were no differences in the observation ratio of the two teams $\left(F_{1,15}\right.$ $=0.05, P=0.83 ; \mathrm{RW} / \mathrm{RR}$ mean $=1.10[\mathrm{SD}=0.34]$, $\mathrm{LW} / \mathrm{WW}$ mean $=1.06[\mathrm{SD}=0.42]$ ), further rejecting the hypothesis that there were substantial observer team effects.

The community contrasts indicated that active riparian and wetland restoration efforts systematically changed the 

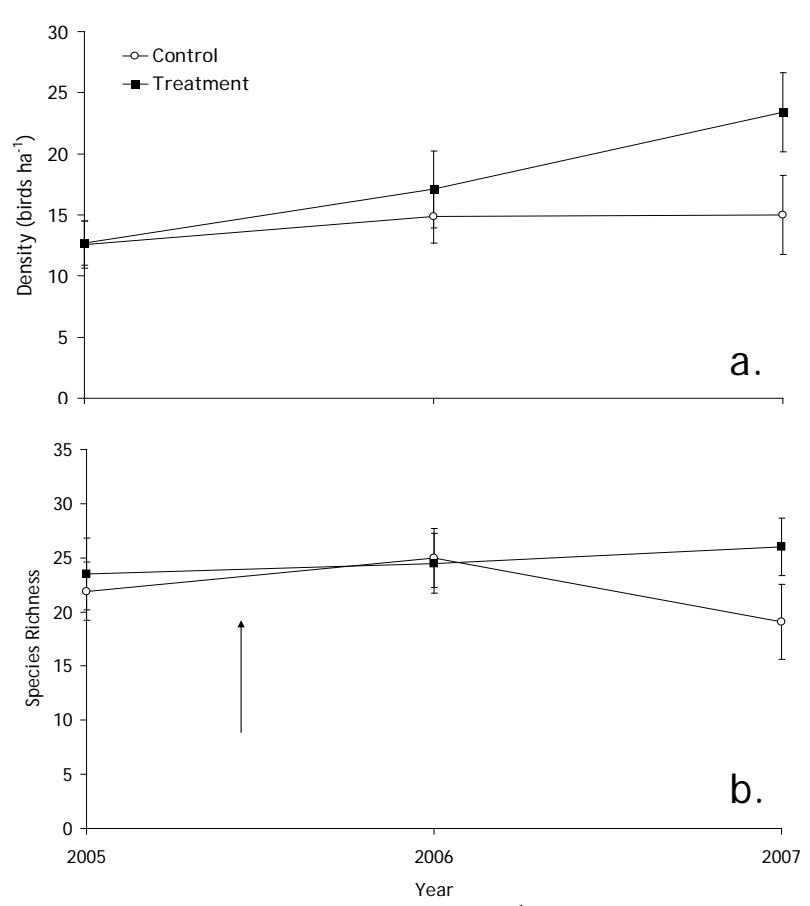

Fig. (4). Average bird densities (birds $\mathrm{ha}^{-1}$ ) between treatment and control plots (a) and species richness (b) across three years of monitoring at Hay Hollow Wash, San Bernardino National Wildlife Refuge, Arizona. Arrows indicate the timing of active restoration efforts. Error bars represent $95 \%$ confidence intervals.

bird communities. Within-year contrasts were most similar, and the contrast of 2005 control plots versus 2007 restored plots was the least similar (Table 1). The restoration efforts increased use by aerialists (e.g., purple martins, Progne subis) and waterbirds (e.g., mallards, Anas platyrhinchos, and spotted sandpipers, Actitis macularia).

Table 1. Contrasts of Avian Community Similarity (Jaccard's Index) Between Control and Restored Plots, Years 2005 and 2007, in Hay Hollow Wash. Higher Values Indicate Greater Community Overlap

\begin{tabular}{|c|c|}
\hline Contrast (Treatment, Year) & Similarity \\
\hline \hline Control '05: Restore '05 & 0.859 \\
\hline Control '07: Restore '07 & 0.687 \\
\hline Control '05: Control '07 & 0.628 \\
\hline Restore '05: Restore '07 & 0.593 \\
\hline Control '05: Restore '07 & 0.571 \\
\hline
\end{tabular}

\section{DISCUSSION}

The active wetland and riparian restoration actions we took in Hay Hollow increased both bird density and community richness. Several papers $[2,19,20]$ have examined how passive restoration efforts, such as the removal of livestock from riparian areas, affect bird populations. Results of these studies demonstrate that most avian populations respond positively to the passive restoration, although populations of guilds that employ open habitats may decline [20]. Our present study demonstrates that bird densities can be further increased by active restoration. Long-term monitoringperhaps five, ten, or more years post-restoration-is required to better understand the implications of active restoration.

Bird density and diversity increases we observed resulted from the large increase in water availability, because the vegetation did not respond sufficiently to explain the broad changes. While we suggest that the increased availability of water was of prime importance to the effects we observed, the relationship is not likely direct. Increased water availability increases the number and diversity of invertebrates [10], which are an important source of protein for breeding and hatchling birds. Over time the abundance of water may translate into additional vegetation that will increase suitable nesting sites for a wider array of birds.

The erosion control work in Hay Hollow Wash resulted in lifting the bed of the incised channel $1.5 \mathrm{~m}$ in two sections. The deposition of sediments reverses the cutting of the channel, slows flood waters, and increases water infiltration rates $[4,21]$. Although there is currently little vegetation response to the water tailed from the wetlands above the wash, the wetted region of the wash received considerable bird use because of the juxtaposition of vegetative cover and available water [5]. We anticipate that flood-resistant aquatic vegetation will become established in the wash in the future, with a concomitant increase in bird densities.

More than one year was required for wetland vegetation to respond to the mesic conditions initiated by active restoration: by the end of 2006, very little marginal vegetation was present around the wetlands (e.g., P. fremontii, B. salicifolia) and there was very little emergent vegetation present within the wetland. However, by mid-2007, a larger number of riparian trees (including Salix gooddingii) were present along the margin and emergent vegetation including Typha dominigensis and Scirpus americana was present. This succession is typical for the area, and should be expected in regions with similar floral components.

Numerous endangered, threatened, or other avian species of concern use riparian and wetland habitats in arid regions of the world. While protecting riparian areas and wetlands from destruction should be the first priority of conservationists, many such areas have already been degraded and investing time, money, and effort in restoration may or may not provide the intended results. Restoring and rehabilitating wetlands and riparian areas is a top land management priority in arid regions, not only because of the wide diversity of organisms that use the habitats $[15,22,23]$, but also because of the ecosystem services provided [24]. If augmenting bird populations is a management goal, then our results suggest that active restoration activities should be pursued in addition to passive restoration because of the additional benefits received from the intensified efforts.

\section{ACKNOWLEDGEMENTS}

We thank R. Webster, R. A. Rowlett, L. Walraven, and W. Walraven for their efforts observing and recording the birds using the study area. The Arizona Bird Conservation Initiative funded this research. J. Malone, M. Drever, and 2 anonymous reviewers for helpful comments that improved the manuscript. 


\section{REFERENCES}

[1] Farley GH, Ellis LM, Stuart JN, Scott NJ. Avian species richness in different-aged stands of riparian forest along the Middle Rio Grande, New Mexico. Cons Bio 1994; 8:1098-1108.

[2] Popotnik GJ, Giuliano WM. Response of birds to grazing of riparian zones. J Wild Mgmt 2000; 64:976-982.

[3] Finch, DM Population ecology, habitat requirements, and conservation of neotropical migratory birds. Tech Rept RM-205 Fort Collins: USDA Forest Service 1991.

[4] Scott ML, Skagen SK, Merigliano MF. Relating geomorphic change and grazing to avian communities in riparian forests. Cons Bio 2003; 17:284-296.

[5] Rood SB, Braatne JH, Hughs FMR. Ecophysiology of riparian cottonwoods: Stream flow dependence, water relations and restoration. Tree Phys 2003; 23:113-1124.

[6] Rood SB, Gourley CR, Ammon EM, et al. Flows for floodplain forests: A successful riparian restoration. Bioscience 2003; 53:647656.

[7] U.S. Fish and Wildlife Service. Fishes of the Rio Yaqui: Recovery Plan. U.S. Fish and Wildlife Service, Albuquerque; 1995.

[8] Petranka JW, Murray SS, Kennedy CA. Responses of amphibians to restoration of a southern Appalachian wetland: Perturbations confound post-restoration assessment. Wetlands 2003; 23:278-290.

[9] Stromberg JC, Wilkins SD, Tress JA. Vegetation-hydrology models: Implications for management of Prosopis velutina (velvet mesquite) riparian ecosystems. Ecol App 1993; 3:307-314.

[10] Taft OW, Colwell MA, Isola CR, Safran RJ. Waterbird responses to experimental drawdown: implications for the multispecies management of wetland mosaics. J App Ecol 2002; 39:987-1001.

[11] Block WM, Franklin AB, Ward JP, Ganey JL, White GC. Design and implementation of monitoring studies to evaluate the success of ecological restoration on wildlife. Restor Ecol 2001; 9:293-303.

[12] Rich TD. Using breeding land birds in the assessment of western riparian systems. Wild Soc Bull 2002; 30:1128-1139.
[13] Lindenmayer DB, Manning AD, Smith PL, et al. The focal-species approach and landscape restoration: A critique. Cons Bio 2002; 16:338-345.

[14] Lanning DV. The vertebrates of San Bernardino Ranch, Cochise County, Arizona. Tucson: Arizona Natural Heritage Program 1981.

[15] Brown DE, Ed. Biotic communities: Southwestern United States and northwestern Mexico. Salt Lake City: University of Utah Press 1994.

[16] Thompson WL. Towards reliable bird surveys: Accounting for individuals present but not detected. Auk 2002; 119:18-25.

[17] Chapman DG. Some properties of the hypergeometric distribution with applications to zoological sample censuses. Univ Cal Pub Stat 1951; 1:131-160.

[18] R Core Development Team. [Homepage on the Internet] R: A language and environment for statistical computing. R Foundation for Statistical Computing, Vienna, Austria. ISBN 3-900051-07-0. [Accessed 2007 August 01] Available at: http://www.R-project.org.

[19] Dobkin DS, Rich AC, Pyle WH. Habitat and avifaunal recovery from livestock grazing in a riparian meadow system of the northwestern Great Basin. Cons Bio 1998; 12:209-221.

[20] Krueper DJ, Bart J, Rich TD. Response of vegetation and breeding birds to the removal of cattle on the San Pedro River, Arizona (USA). Cons Bio 2003; 17:607-615.

[21] Wilcox BP, DD Breshears, Allen CD. Ecohydrology of a resourceconserving semiarid woodland: effects of scale and disturbance. Ecol Mono 2003; 73:223-239.

[22] Shaw DW, Finch DM. Desired future conditions for Southwestern riparian ecosystems: Bringing interests and concerns together. Gen Tech Rept RM-GTR-272. Fort Collins: USDA Forest Service 1996.

[23] Gabbe AP, Robinson SK, Brawn JD. Tree-species preferences of foraging insectivorous birds: Implications for floodplain forest restoration. Cons Bio 2002; 16:462-470.

[24] Diaz S, Fargione J, Chapin FS III, Tilman D. Biodiversity loss threatens human well-being. PLoS Biology 2006; 4:e277. DOI:10.1371/journal.pbio.0040277.

Received: December 07, 2007 Revised: May 14, $2008 \quad$ Accepted: May 15, 2008

(C) Malcom and Radke; Licensee Bentham Open.

This is an open access article licensed under the terms of the Creative Commons Attribution Non-Commercial License (http://creativecommons.org/licenses/by-nc/3.0/) which permits unrestricted, non-commercial use, distribution and reproduction in any medium, provided the work is properly cited. 
Appendix 1. Species across all plots and all years in Hay Hollow, San Bernardino National Wildlife Refuge, Douglas, Arizona. Species codes follow the American Ornithologists Union.

\begin{tabular}{|c|c|c|c|c|c|c|c|c|c|c|c|}
\hline & 2005 & 2006 & 2007 & & 2005 & 2006 & 2007 & & 2005 & 2006 & 2007 \\
\hline ATFL & $X$ & $X$ & $X$ & GAQU & $X$ & $X$ & $X$ & PABU & & $X$ & \\
\hline BAOW & & & $X$ & GBHE & & $\mathrm{X}$ & $X$ & PHAI & $X$ & $X$ & $X$ \\
\hline BARS & & $X$ & $X$ & GHOW & $\mathrm{X}$ & $X$ & $X$ & PISI & $X$ & & \\
\hline BCFL & $X$ & $X$ & $X$ & GIWO & $X$ & $X$ & $X$ & PUMA & & & $X$ \\
\hline $\mathrm{BCHU}$ & $X$ & $X$ & $X$ & GRFL & $X$ & $X$ & $X$ & PYRR & & $X$ & $\mathrm{X}$ \\
\hline BEVI & $X$ & $X$ & $X$ & GRHA & & & $X$ & RCKI & & $X$ & \\
\hline BEWR & $\mathrm{X}$ & $\mathrm{X}$ & $\mathrm{X}$ & GRRO & $\mathrm{X}$ & $\mathrm{X}$ & $X$ & RCSP & $X$ & $X$ & $X$ \\
\hline BGGN & $X$ & & & GRWA & & & $X$ & ROWR & $\mathrm{X}$ & $X$ & \\
\hline $\mathrm{BHCO}$ & $X$ & $\mathrm{X}$ & $\mathrm{X}$ & GTTO & $\mathrm{X}$ & $X$ & $X$ & RTHA & $X$ & & $\mathrm{X}$ \\
\hline BHGR & $X$ & $X$ & $X$ & HAFL & & & $X$ & RWBL & & $X$ & \\
\hline BLGR & $X$ & $X$ & $X$ & HEWA & & $X$ & $X$ & SAPH & $X$ & $X$ & $X$ \\
\hline BLPH & & $X$ & $X$ & HOFI & $X$ & $X$ & $X$ & SCOR & $X$ & $X$ & \\
\hline BOSP & $X$ & $X$ & $X$ & HOOR & $X$ & $X$ & & SCQU & & $X$ & \\
\hline BRSP & & $\mathrm{X}$ & $\mathrm{X}$ & HOWR & & $X$ & $X$ & SPSA & & $X$ & \\
\hline BTGN & $X$ & $X$ & $X$ & INBU & & & $X$ & SUTA & $\mathrm{X}$ & $X$ & $X$ \\
\hline BTHU & & $X$ & & KILL & & $X$ & & TOWA & & $X$ & $X$ \\
\hline BTSP & $X$ & $\mathrm{X}$ & $X$ & LABU & $\mathrm{X}$ & $X$ & $X$ & TRES & & & $X$ \\
\hline BTYW & $X$ & $X$ & $X$ & LASP & $X$ & $X$ & $X$ & TUVU & & & $X$ \\
\hline BUOR & $X$ & $\mathrm{X}$ & $\mathrm{X}$ & LAZB & $\mathrm{X}$ & $X$ & $X$ & VABU & $X$ & $\mathrm{X}$ & $X$ \\
\hline CAKI & $X$ & $X$ & $X$ & LBWO & $X$ & $X$ & $X$ & VEFL & $X$ & $X$ & $X$ \\
\hline
\end{tabular}




\begin{tabular}{|c|c|c|c|c|c|c|c|c|c|c|c|}
\hline$\overline{\text { CANT }}$ & $\mathrm{X}$ & $\mathrm{X}$ & $\mathrm{X}$ & LEGO & & $\mathrm{X}$ & & VERD & $\mathrm{X}$ & $\mathrm{X}$ & $\mathrm{X}$ \\
\hline CASP & $X$ & $X$ & X & LENI & X & X & & VESP & & & X \\
\hline CAVI & & & X & LISP & X & & X & VGSW & & X & \\
\hline CBTH & X & & & LOSH & X & $X$ & $\mathrm{X}$ & VIWA & & & X \\
\hline CHRA & $X$ & & & LUWA & $\mathrm{X}$ & $X$ & $X$ & WAVI & $\mathrm{X}$ & $\mathrm{X}$ & $X$ \\
\hline CHSP & $X$ & $X$ & X & MALL & & & $X$ & WCSP & X & $X$ & X \\
\hline CLSW & & $X$ & & MGWA & $X$ & & $X$ & WEFL & & $X$ & \\
\hline COFL & $X$ & & & MODO & X & $X$ & $\mathrm{X}$ & WEKI & X & $X$ & X \\
\hline COGD & X & $\mathrm{X}$ & X & NAWA & X & X & & WETA & X & X & X \\
\hline COHA & X & X & X & NBTY & X & X & X & WIFL & & $X$ & \\
\hline $\mathrm{COHU}$ & & X & & NOCA & X & $X$ & X & WIWA & X & X & X \\
\hline CORA & & & $\mathrm{X}$ & NOFL & $\mathrm{X}$ & & & WWDO & X & X & $X$ \\
\hline COYE & $X$ & & X & NOMO & X & $X$ & $X$ & WWPE & $\mathrm{X}$ & $X$ & $X$ \\
\hline CRTH & X & X & X & NOWA & & & $\mathrm{X}$ & YBCH & X & X & X \\
\hline DUFL & & $\mathrm{X}$ & X & NRWS & & $\mathrm{X}$ & $\mathrm{X}$ & YBCU & & X & \\
\hline ECDO & & $\mathrm{X}$ & & OCWA & & X & $\mathrm{X}$ & YRWA & X & $X$ & X \\
\hline Empid & & & $\mathrm{X}$ & PARE & $\mathrm{X}$ & & & YWAR & $\mathrm{X}$ & X & $\mathrm{X}$ \\
\hline
\end{tabular}

